\title{
OCCURRENCE AND DISAPPEARANCE OF PARATHION AND MALATHION RESIDUES IN VEGETABLES AND FRUITS
}

\author{
Pekka Koivistoinen and Paavo Roine, \\ with technical assistance from KIRSTI JOKELA
}

Department of Nutritional Chemistry, University of Helsinki, Finland

Received August 28, 1959

Since the use of pesticides, most of which are poisonous to humans, has rapidly increased in agriculture, especially in the past decade, it is of great importance from the standpoint of public health to investigate the occurrence of residues of these compounds in food products. For this reason extensive determinations of residues have already been carried out in many countries.

In Finland the use of pesticides has not reached the same proportions as in many other countries. Nevertheless we have considered it essential at this stage to direct attention to the question of residues in food products. Since the insectiside most commonly employed in Finland (9) is parathion $(O, O$-diethyl $O$ - $p$-nitrophenyl thiophosphate) which is extremely toxic to warmblooded animals, we have paid attention especially to this compound. At the same time studies have been made on malathion, its related compound [O,O-dimethyl $S$-(1,2-dicarboethoxyethyl)dithiophosphate], which is relatively harmless to warmblooded animals (5) but which is, nevertheless, one of the best insecticides (6). The rates of disappearance of parathion and malathion residues on different fruits and vegetables, as well as the fate of such residues during processes of conserving and storage of certain fruit and vegetable products have so far been investigated.

\section{Methods}

\section{Extraction and purification}

The extraction of the pesticides was generally carried out within two hours after the collection of the samples. $0.5 \mathrm{~kg}$ of plant material was macerated in $350 \mathrm{ml}$ of $94 \%$ ethyl alcohol in a $1500 \mathrm{ml}$ glass container for $1 \mathrm{~min}$. in a Top Drive Macerator. The macerator was rinsed with $150 \mathrm{ml}$ of ethyl alcohol which was added to the macerated extract. $500 \mathrm{ml}$ of benzene were then added and the process of extraction was carried out for 1 hour on a drum-tumbler stripper (44 r.p.m.); during this time the benzene phase separated from the water-alcohol phase. 
The extract was strained through cheesecloth into a $1000 \mathrm{ml}$ separatory funnel. When the two phases had separated, the water-alcohol layer was drained and discarded, and the benzene layer was washed twice with saturated $\mathrm{NaCl}$ solution.

For purifying the benzene extract a mixture was used consisting of $50 \%$ Nuchar C-190-N (Industrial Chemical Sales, USA), $25 \%$ Hyflo Super Cel (L. Light \& Co. Ltd., England) and $25 \%$ anhydrous sodium sulphate (May \& Baker Ltd., England). Ten grams of this mixture were added to $250 \mathrm{ml}$ of benzene extract and mixed for $5 \mathrm{~min}$. on the drum-tumbler stripper. The purified benzene was filtered and two samples of $100 \mathrm{ml}$ were taken for the final parathion and malathion determinations.

\section{Determination of parathion}

The Gunther and Blinn (4) modification of the Averell and Norris method (1) for the determination of parathion was originally attempted, but this method gave unsatisfactory results, presumably due to an inadequate reduction of the parathion. After preliminary tests, the procedure was changed in such a way that the reduction was carried out in a benzene-water-alcohol mixture of increased acidity. The following procedure was employed:

$100 \mathrm{ml}$ of purified benzene extract was evaporated under reduced pressure to a volume of $10 \mathrm{ml}$. To this was added $8 \mathrm{ml} 30 \%$ ethyl alcohol, $0.5 \mathrm{~g}$ zinc powder and $2 \mathrm{ml}$ of conc. $\mathrm{HCl}$ (S.G. 1.16). The reduction was carried out for $10 \mathrm{~min}$. on a water bath under a reflux condensor. The mixture was allowed to cool and was filtered through cotton into a $50 \mathrm{ml}$ separatory funnel where the benzene and water-alcohol phases separated. The reduction flask, funnel and benzene were twice washed with $5 \mathrm{ml} 30 \%$ ethyl alcohol. The water-alcohol phase was collected in a $50 \mathrm{ml}$ volumetric flask and $4 \mathrm{ml} 94 \%$ ethyl alcohol were added, after which the $\mathrm{pH}$ was about 0.8 . One $\mathrm{ml} 0.25 \%$ sodium nitrite was added, the flask was shaken $15 \mathrm{sec}$. and allowed to stand $10 \mathrm{~min} .1 \mathrm{ml} 2.5 \%$ ammonium sulfamate solution was then added, shaken $15 \mathrm{sec}$. and allowed to stand $10 \mathrm{~min}$. Finally $2 \mathrm{ml} 1 \% \mathrm{~N}$-(l-naphthyl)-ethylenediamine dihydrochloride solution were added, shaken $15 \mathrm{sec}$. and after $10 \mathrm{~min}$. the flask was filled to the mark with acidified ethyl alcohol $(100 \mathrm{ml} 99.5 \%$ ethyl alcohol, $12 \mathrm{ml}$ conc. $\mathrm{HCl}$ ). The optical density of the resulting coloured solution was determined by a Beckman DU spectrophotometer at $555 \mathrm{~m} \mu$ using an $1 \mathrm{~cm}$ cuvette.

A standard calibration curve was prepared with parathion which had been purified according to the method of EDWARDS and HALL (3).

Simultaneously with each determination a control test was made using untreated plant material. The value of this control absorbance was subtracted from that obtained with the treated material.

Paranitrophenol added to the plant material had no influence upon the obtained results.

In order to test the precision of the method, known amounts of parathion were added to different plant materials before maceration, after which determinations were made in the ordinary manner. The results of these test (Table 1) show that the error of recovery was at the most $\pm 0.1 \mathrm{ppm}$, which represents an error of $\pm 10 \%$ at the level of 1 ppm. 
Table 1. Precision of the parathion determination method

\begin{tabular}{|c|c|c|c|c|}
\hline \multirow[t]{2}{*}{ Plant material } & \multicolumn{4}{|c|}{ Parathion } \\
\hline & $\begin{array}{c}\text { added } \\
\text { ppm }\end{array}$ & $\begin{array}{c}\text { recovered } \\
\text { ppm }\end{array}$ & $\begin{array}{l}\text { difference } \\
\text { ppm }\end{array}$ & $\begin{array}{c}\text { recovery } \\
\%\end{array}$ \\
\hline \multirow[t]{3}{*}{ Apple } & 0.20 & 0.21 & +0.01 & 105 \\
\hline & 1.00 & 0.91 & -0.09 & 91 \\
\hline & 2.00 & 1.94 & -0.06 & 97 \\
\hline \multirow[t]{3}{*}{ Black currant } & 0.20 & 0.20 & 0.00 & 100 \\
\hline & 1.00 & 1.00 & 0.00 & 100 \\
\hline & 2.00 & 2.01 & +0.01 & 101 \\
\hline \multirow[t]{3}{*}{ Cabbage } & 0.20 & 0.22 & +0.02 & 110 \\
\hline & 1.00 & 0.98 & -0.02 & 98 \\
\hline & 2.00 & 2.00 & 0.00 & 100 \\
\hline Cucumber & 1.00 & 0.95 & -0.05 & 95 \\
\hline \multirow[t]{3}{*}{ Gooseberry } & 0.20 & 0.19 & -0.01 & 95 \\
\hline & 1.00 & 1.08 & +0.08 & 108 \\
\hline & 2.00 & 2.07 & +0.07 & 104 \\
\hline \multirow[t]{2}{*}{ Lettuce } & 0.20 & 0.23 & +0.03 & 115 \\
\hline & 1.00 & 1.05 & +0.05 & 105 \\
\hline & 2.00 & 2.03 & +0.03 & 102 \\
\hline Spinach & 1.00 & 0.95 & -0.05 & 95 \\
\hline Strawberry & 1.00 & 1.06 & +0.06 & 106 \\
\hline Stringbean & 1.00 & 0.96 & -0.04 & 96 \\
\hline
\end{tabular}

\section{Determination of malathion}

In the method of NorRis et al. (7) for the determination of malathion residues as well as in Conroy's modification of this method (2), carbon tetrachloride is employed as the extracting solvent. In the present work, however, carbon tetrachloride was replaced by benzene and thus the same extraction and purification procedures as for parathion could be used. The determination was carried out as follows:

$100 \mathrm{ml}$ of purified benzene extract was put into a $250 \mathrm{ml}$ separatory funnel to which were added $25 \mathrm{ml} 99.5 \%$ ethyl alcohol and $1 \mathrm{ml} 6 \mathrm{~N} \mathrm{NaOH}$. The funnel was immediately shaken vigorously for exactly $1 \mathrm{~min}$. When the water layer had separated, it was drawn off into a second $250 \mathrm{ml}$ separatory funnel. $25 \mathrm{ml}$ carbon tetrachloride were added, shaken $15 \mathrm{sec}$. and the carbon tetrachloride was drained and discarded. $25 \mathrm{ml}$ carbon tetrachloride were again added and the solution was neutralized with $6 \mathrm{~N} \mathrm{HCl}$ using phenolphtalein as indicator. To this was added $1 \mathrm{ml}$ of acidic ferric chloride solution $\left(5 \mathrm{~g} \mathrm{FeCl}_{3} \cdot 6 \mathrm{H}_{2} \mathrm{O}\right.$ in $\left.100 \mathrm{ml} 1 \mathrm{~N} \mathrm{HCl}\right)$, the mixture was shaken $30 \mathrm{sec}$. and the carbon tetrachloride drained and discarded. The water phase was treated two more times with $25 \mathrm{ml}$ carbon tetrachloride with a shaking of $30 \mathrm{sec}$. After the second carbon tetrachloride portion had been drained, excatly $25 \mathrm{~m}$ ! carbon tetrachloride and $1 \mathrm{ml}$ copper sulphate solution $\left(3.5 \mathrm{~g} \mathrm{CuSO}_{4} \cdot 5 \mathrm{H}_{2} \mathrm{O}\right.$ in $100 \mathrm{ml}$ water) were added and shaken vigorously $1 \mathrm{~min}$. The carbon tetrachloride phase 
was filtered through cotton into an $1 \mathrm{~cm}$ cuvette and within 5 minutes after the last shaking the optical density was determined by a Beckman DU spectrophotometer at $418 \mathrm{~m} \mu$. All the reagents used in this procedure were of reagent grade. A standard calibration curve was prepared for pure malathion ${ }^{1)}$ by adding known amounts of this compound to macerated apple pulp.

Simultaneously with each determination a control test was made using untreated plant material. The value of this control absorbance was subtracted from that obtained with the treated material.

Table 2. Precision of the malathion determination method

\begin{tabular}{|c|c|c|c|c|}
\hline \multirow[t]{2}{*}{ Plant material } & \multicolumn{4}{|c|}{ Malathion } \\
\hline & $\begin{array}{c}\text { added } \\
\text { ppm }\end{array}$ & $\begin{array}{l}\text { recovered } \\
\text { ppm }\end{array}$ & $\begin{array}{l}\text { difference } \\
\text { ppm }\end{array}$ & $\begin{array}{c}\text { recovery } \\
\%\end{array}$ \\
\hline Black currant & 8.0 & 8.3 & +0.3 & 104 \\
\hline Broccoli & 8.0 & 7.8 & -0.2 & 97 \\
\hline Cucumber & 8.0 & 7.7 & -0.3 & 96 \\
\hline Lettuce & 8.0 & 8.4 & +0.4 & 105 \\
\hline Pea (with pod) & 2.0 & 1.9 & -0.1 & 95 \\
\hline & 8.0 & 7.3 & -0.7 & 109 \\
\hline & 16.0 & 15.8 & -0.2 & 99 \\
\hline Spinach & 8.0 & 7.6 & -0.4 & 95 \\
\hline Strawberry & 8.0 & 8.2 & +0.2 & 103 \\
\hline Stringbean & 2.0 & 2.0 & 0.0 & 100 \\
\hline & 8.0 & 7.6 & -0.4 & 95 \\
\hline & 16.0 & 15.5 & -0.5 & 97 \\
\hline
\end{tabular}

In order to test the precision of the method, different plant materials were fortified with known amounts of malathion before maceration and determinations were made. The results of these tests (Table 2) show that the precision of this method is very high, the error being in general less than $\pm 5 \%$.

Experiments and results

\section{Disappearance of residues}

Application of pesticides to plants. The following plant species and varieties were used: pea (Rival/50 OE), cucumber (Perseus), lettuce (Penlake), strawberry (Abundance), black currant (Brödtorp), apple (Snygg), stringbean (Spässerud), broccoli (Delikat) and New Zealand spinach. The plants were sprayed once with

1 We are indebted to the American Cyanamid Company for supplying us with a sample of pure malathion. 
emulsions of parathion or malathion containing $0.019 \%$ and $0.1 \%{ }^{1)}$, respectively, of the active ingredient (parathion E $60535 \%$, Bayer; malathion $50 \%$, Amer. Cyanamid Co.). The plants were wetted completely with the spray in order that the initial deposit would be as uniform as possible throughout the entire experimental area. Each of the plant species was treated at the same time with both parathion and malathion, on separate plots, approximately two weeks before the normal harvest.

Sampling. Samples $(0.5-2.0 \mathrm{~kg})$ were taken of the edible portions of the plants from both the treated and the untreated areas. The first samples were collected directly after spraying as soon as the plants had become dry; subsequent samplings were made after 3 and 7 days, and thereafter at one-week intervals.

Table 3. Residues of parathion and malathion on different fruits and vegetables

\begin{tabular}{|c|c|c|c|c|c|c|c|c|}
\hline \multirow{3}{*}{ Plant } & \multicolumn{4}{|c|}{ Parathion } & \multicolumn{4}{|c|}{ Malathion } \\
\hline & \multicolumn{3}{|c|}{ Reduction } & \multicolumn{5}{|c|}{ Reduction } \\
\hline & $\begin{array}{l}\text { Initial } \\
\text { deposit, } \\
\text { ppm }\end{array}$ & $\begin{array}{l}\text { below } \\
1 \text { ppm, } \\
\text { days }\end{array}$ & $\begin{array}{l}\text { Detect- } \\
\text { able } \\
\text { qualitati- } \\
\text { vely, }^{1} \\
\text { days }^{-}\end{array}$ & $\begin{array}{l}\text { Half- } \\
\text { life, } \\
\text { days }\end{array}$ & $\begin{array}{c}\text { Initial } \\
\text { deposit, } \\
\text { ppm }\end{array}$ & $\begin{array}{c}\text { below } \\
8 \text { ppm, } \\
\text { days }\end{array}$ & $\begin{array}{l}\text { Detect- } \\
\text { able } \\
\text { qualitati- } \\
\text { vely, }^{1} \\
\text { days }\end{array}$ & $\begin{array}{l}\text { Half- } \\
\text { life, } \\
\text { days }\end{array}$ \\
\hline Apple $\ldots \ldots \ldots \ldots \ldots \ldots$ & 1.05 & 1 & 28 & 3 & 1.8 & 0 & 14 & 2 \\
\hline Bean $\quad \ldots \ldots \ldots \ldots \ldots \ldots$ & 2.14 & 3 & 14 & 3 & 6.4 & 0 & 14 & 1 \\
\hline Black currant $\ldots \ldots \ldots \ldots$ & 9.77 & 15 & 43 & 2 & 28.4 & 4 & 28 & 2 \\
\hline Broccoli $\ldots \ldots \ldots \ldots \ldots$ & 14.60 & 8 & 14 & 1 & 40.0 & 2 & 14 & 1 \\
\hline Cucumber $\quad \ldots \ldots \ldots \ldots \ldots$ & 0.49 & 0 & 7 & 1 & $<0.5$ & 0 & 3 & - \\
\hline Lettuce $\quad \ldots \ldots \ldots \ldots \ldots$ & 4.58 & 2 & 14 & 1 & 22.6 & 1 & 14 & 1 \\
\hline Pea $\ldots \ldots \ldots \ldots \ldots \ldots \ldots$ & 1.05 & 1 & 14 & 1 & 1.7 & 0 & 7 & 1 \\
\hline Spinach $\ldots \ldots \ldots \ldots \ldots$ & 12.05 & 6 & 28 & 1 & 49.8 & 3 & 7 & 1 \\
\hline Strawberry ........... & $3.25^{2}$ & 3 & 14 & 1 & $5.0^{2}$ & 1 & 7 & 1 \\
\hline
\end{tabular}

1 The method for parathion about 5 times more sensitive than that for malathion.

2 Half a day after spraying.

Results. Table 3 shows that the initial deposits of parathion varied between 0.49 and $14.60 \mathrm{ppm}$, depending on the plant. In all the plants except cucumber these values exceeded the tolerance limit of $1 \mathrm{ppm}$ which is used in the U.S. (8) The time required for the parathion residues to decrease below $1 \mathrm{ppm}$ was longest for black currant ( 15 days) and relatively long also for broccoli ( 8 days) and spinach ( 6 days). Parathion could be found qualitatively in black currant, using the previously described method, as long as 43 days after spraying and in spinach 28 days after spraying. The half-life of the parathion residues was $1-3$ days.

In the case of malathion, the initial deposits varied from less than 0.5 to 49.8 $\mathrm{ppm}$. In four cases the values were under the tolerance limit of $8 \mathrm{ppm}$ (pea, cucumber, apple and bean). The residues which initially exceeded the tolerance limit reached

1 Apple and black currant were treated with $0.075 \%$ malathion spray. 
this limit more rapidly than with parathion, requiring, at the longest, 4 days for black currant. Malathion could be detected qualitatively, using the previously described method, for the longest time in black currant (28 days after spraying). The half-life of malathion residues was $1-2$ days, i.e. slightly shorter than for parathion.

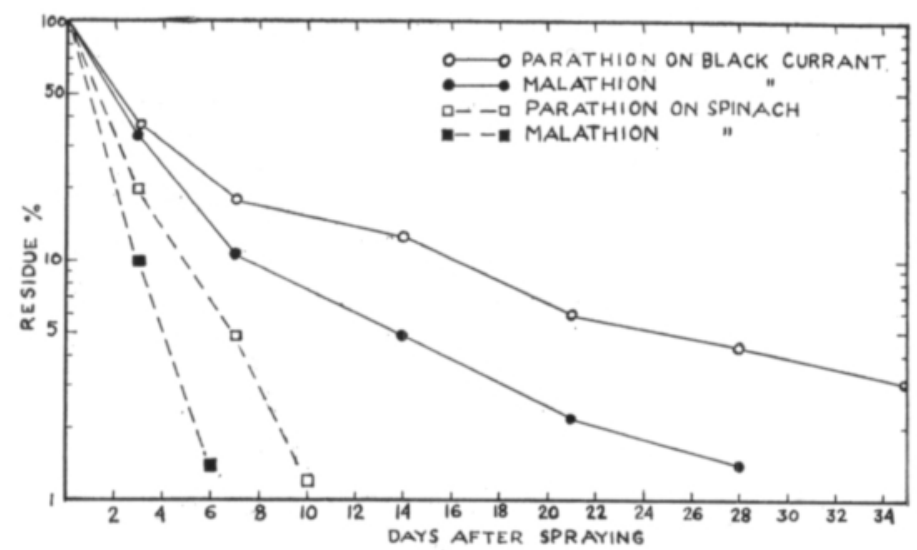

Fig. 1. Disappearance of parathion and malathion residues on black currant and spinach.

In Figure 1 are shown the rates of disappearance of parathion and malathion in two of the plants, black currant and spinach. This figure shows that the two compounds disappear in the same manner, malathion only slightly more rapidly than parathion. Between the plants however, a distinct difference is seen. On the black currant a very persistent residue of both pesticides remained, whereas on spinach the residues disappeared according to the principle of degradation at least to the value of $1 \%$ of the initial deposit.

\section{Conservation and storage experiments}

Since the trials on the rate of disappearance of parathion and malathion residues showed that very persistent residues remained in black currant, additional experiments were carried out in order to determine the presence of the residues in various types of conserves prepared from black currant.

Samples of black currant (Brödtorp) were collected which had been sprayed 4 days previously and which contained $1.22 \mathrm{ppm}$ parathion and $5.0 \mathrm{ppm}$ malathion at the time the conserving processes were carried out. Using samples of both sprayed and unsprayed berries, steam-juice and two types of jam were prepared; in addition, the berries were frozen and stored.

Preparation of steam-juice. The steam-juice was prepared in an aluminum steam extraction kettle (Saftborn) in which steam was allowed to act for one hour upon a mixture of berries and sugar (750 g sucrose, $1 \mathrm{~kg}$ berries), after which the juice was collected in 0.5 -litre bottles which were sealed with a rubber cap. The bottles 
were kept in the dark at 0 to $+5^{\circ} \mathrm{C}$. Determinations of parathion and malathion were made immediately after the processing and then several times during a period of 6 months.

Preparation of jam I. One kilogram of black currants and $750 \mathrm{~g}$ sucrose were put in layers in an aluminum kettle and allowed to stand overnight. The mixture was then cooked $10 \mathrm{~min}$. and $550 \mathrm{~g}$ portions of the jam were put in glass jars which were sealed with melted paraffin. Storage and determination of residues were the same as for the juice.

Preparation of jam II. Jam II was prepared from $1 \mathrm{~kg}$ black currants, $350 \mathrm{ml}$ water, $750 \mathrm{~g}$ sucrose and $10 \mathrm{~g}$ "Hillox" preservative (containing a benzoic acid derivative). The sugar was added to boiling water in an aluminum kettle and cooked for $10 \mathrm{~min}$. When the solution had slightly cooled, the berries were added and cooked for $15 \mathrm{~min}$. After the jam had cooled, the preservative was mixed into it. The jam was put in jars and sealed with paraffin; storage and determination of residues were the same as for the juice.

Frozen storage trial. For the freezing trials black currants and spinach leaves were used, both untreated products as controls as well as products sprayed with parathion and malathion. The black currants used were from the same sampling as those used in the preparation of the juice and jams. They were stored in $550 \mathrm{~g}$ portions in cardboard boxes lined and covered with waxpaper. The spinach leaves were collected 6 days after parathion spraying and 2 days after malathion spraying, at the time of collection they contained $2.7 \mathrm{ppm}$ parathion and $33.1 \mathrm{ppm}$ malathion. The spinach was stored in closed plastic bags. Freezing and storage were carried out at -10 to $-15^{\circ} \mathrm{C}$.

Table 4. Decrease in parathion and malathion residues during the processing of black currants

\begin{tabular}{|c|c|c|c|c|c|c|}
\hline \multirow{3}{*}{$\begin{array}{l}\text { Type of } \\
\text { conserve }\end{array}$} & \multicolumn{3}{|c|}{ Parathion } & \multicolumn{2}{|c|}{ Malathion } & \multirow{3}{*}{$\begin{array}{c}\text { loss in } \\
\text { processing } 1 \\
\%\end{array}$} \\
\hline & in the berries & in the conserve & $\begin{array}{c}\text { loss in } \\
\text { processing } 1\end{array}$ & in the berries & in the conserve & \\
\hline & ppm & ppm & $\%$ & ppm & ppm & \\
\hline Steam-juice & 1.22 & 0.06 & 94 & 5.0 & 0.6 & 86 \\
\hline Jam I & 1.22 & 0.34 & 54 & 5.0 & 0.9 & 71 \\
\hline Jam II & 1.22 & 0.42 & 30 & 5.0 & 1.3 & 54 \\
\hline
\end{tabular}

1 Changes in weight have been taken into consideration.

Results. Table 4 shows that when steam-juice was prepared from treated black currants $94 \%$ of the parathion and $86 \%$ of the malathion had either been destroyed or remained in the berries. In jam I $54 \%$ of the parathion and $71 \%$ of the malathion were destroyed during the preparation, in jam II 30 and 54, respectively. In both of the methods of jam preparation malathion was destroyed to a greater degree than parathion. 
The disappearance of the residues during storage is shown in Table 5. It can be seen that in all three of the black currant preparations both parathion and malathion persisted nearly completely. In addition, both compounds were very stable in the frozen products.

Table 5. Decrease in parathion and malathion residues during storage (ppm)

\begin{tabular}{|c|c|c|c|c|c|c|c|c|c|c|}
\hline \multirow[t]{2}{*}{$\begin{array}{c}\text { Time of storage, } \\
\text { months }\end{array}$} & \multicolumn{2}{|c|}{ Steam-juice } & \multicolumn{2}{|c|}{ Jam I } & \multicolumn{2}{|c|}{ Jam II } & \multicolumn{2}{|c|}{$\begin{array}{l}\text { Black currants } \\
\text { frozen }\end{array}$} & \multicolumn{2}{|c|}{$\begin{array}{l}\text { Spinach } \\
\text { frozen }\end{array}$} \\
\hline & P. ${ }^{1}$ & $\mathrm{M}^{2}{ }^{2}$ & P. & M. & P. & M. & P. & M. & P. & M. \\
\hline 0 & 0.06 & 0.6 & 0.34 & 0.9 & 0.42 & 1.3 & 1.22 & 5.0 & 2.66 & 29.2 \\
\hline 6 & 0.02 & 0.3 & 0.32 & 1.1 & 0.41 & 0.9 & 1.15 & 4.8 & 2.41 & 22.0 \\
\hline
\end{tabular}

$1 \mathrm{P}$. = parathion

${ }^{2}$ M. = malathion

$S u m m$ ary

Disappearance of parathion and malathion residues in 9 different kinds of fruits and vegetables (pea, cucumber, lettuce, strawberry, black currant, apple, stringbean broccoli and spinach) sprayed about two weeks before the normal harvest was investigated. In addition, experiments were made on the effects of 3 different conserving processes upon the residues on black currant as well as on the persistence of the residues in conserves and frozen products during storage. The determination of parathion was carried out by a modification of the method of AVERELL and NoRRIS, using a benzene-water-alcohol mixture and increased acidity in the reduction. The malathion was determined by the method of NorRIS et al. with the modification of benzene used as the extracting solvent instead of carbon tetrachloride. The procedures for the determination of total residues in plants are described in detail.

The initial deposits of parathion varied from 0.49 to $14.60 \mathrm{ppm}$ and those of malathion from less than 0.5 to $49.8 \mathrm{ppm}$, depending on the plant species. The halflife of the residues was $1-3$ and $1-2$ days, respectively. The most persistent residues were found in black currant; in these berries malathion could be determined qualitatively 28 days and parathion at least 43 days after spraying. Very small residues were found in the steam-juice prepared from black currants. In the preparation of two kinds of jam, 30 and $54 \%$ of the parathion and 54 and $71 \%$ of the malathion were destroyed. Both of the pesticides were very stable in black currant conserves as well as in frozen products for a period of at least 6 months. 


\section{LITERATURE}

(1) Averell, P. R. \& Norris, M. V. 1948. Estimation of small amounts of $O, O$-diethyl $O$-p-nitrophenyl thiophosphate. Anal. Chem. 20: 753-756.

(2) Conroy, H. W. 1957. Report on malathion. J. Assoc. Off. Agr. Chemists 40: 230-235.

(3) Edwards, F. I., Jr. \& Hall, S. A. 1949. Purification of $O, O$-diethyl $O$ - $p$-nitrophenyl thiophosphate (parathion) for use as a primary standard. Anal. Chem. 21: 1567-1568.

(4) Gunther, F. A. \& Blinn, R. C. 1955. Analysis of insecticides and acaricides. Chem. Anal. 6: $1-696$.

(5) Hazleton, L. W. \& Holland, E. G. 1953. Toxicity of malathion. Summary of mammalian investigations. Arch. Ind. Hyg. Occupational Med. 8: $399-405$.

(6) Johnson, G. A. \& Fletcher, J. H. et al. 1952. Decreased toxicity and cholinesterase inhibition in a new series of dithiophosphates. J. Econ. Ent. 45: 279-283.

(7) Norris, M. V. \& VAIL, W. A. \& Averell, P. R. 1954. Colorimetric estimation of malathion residues. J. Agr. Food Chem. 2: 570-573.

(8) Official FDA tolerances. 1957. Nat. Agr. Chem. Assoc. News Pesticide Rev. 15, 4: 5-14.

(9) Rorvanen, S. 1958. Kasvinsuojeluaineiden myynti Suomessa vuonna 1957. (Summary: Sales of plant-protection chemicals in Finland 1957). Tekn. kem. aikak. 15: $384-388$.

S E L O S T U S:

\section{PARATIONIN JA MALATIONIN JÄÄMIEN ESIINTYMISESTÄ KASVITUOTTEISSA}

Pekka Korvistoinen ja PaAvo Roine

Helsingin yliopiston ravintokemian laitos

Tässä tutkimuksessa on selvitetty parationin ja malationin jäämien esiintymistä yhdeksän eri kasvilajin syötävissä osissa (taittoherne, kasvihuonekurkku, keräsalaatti, mansikka, mustaherukka, omena, papu, parsakaali ja Uuden Seelannin pinaatti). Kasvit oli ruiskutettu noin kaksi viikkoa ennen normaalia sadonkorjuuta 0.019-prosenttisella parationi- ja 0.075- tai 0.1-prosenttisella malationiemulsiolla aivan märiksi. Lisäksi on tutkittu höyrymehustamisen ja kahden hilloamismenetelmän vaikutusta mustaherukassa esiintyneisiin jäämiin samoin kuin aineiden pysyvyyttä eräissä säilykkeissä ja jäädytetyissä tuotteissa kuusi kuukautta kestäneen varastoinnin aikana. Parationi määritettiin modifioidulla Averellin ja Norrisin menetelmällä sekä malationi modifioidulla NorRIsin ym. menetelmällä.

Parationin alkujäämät olivat kasvilajista riippuen $0.49-14.60$ milj.osaa. Kaikissa muissa kasvituotteissa paitsi kurkussa saadut arvot ylittivät esim. U.S.A:ssa parationille asetetun toleranssirajan, 1 milj.osan. Kahdessa viikossa jäämät kuitenkin, mustaherukkaa lukuunottamatta, laskivat alle mainitun rajan. Malationin alkujäämät vaihtelivat puolestaan alle 0.5:stä 49.8 milj.osaan. Neljässä tapauksessa jo alkujäämät olivat alle malationille käytetyn toleranssirajan, 8 milj. osaa. Tätä suuremmat jäämät laskivat nopeasti sen alapuolelle, mustaherukassakin jo 4 vrk:ssa. Paarationin jäämät laskivat puoleen alkuarvostaan $1-3$ ja malationin $1-2$ vrk:ssa. Pysyvimmät jäämät esiintyivät mustaherukassa: Malationi voitiin osoittaa siitä kvalitatiivisesti vielä 28 ja parationi ainakin 43 vrk:n kuluttua ruiskutuksesta. Höyrymehuun myrkkyjä joutui hyvin vähän. Hilloamisessa tuhoutui parationia 30 ja 54 \% sekä malationia 54 ja $71 \%$. Mustaherukasta valmistetuissa säilykkeissä sekä jäädytetyssä mustaherukassa ja pinaatissa molemmat aineet olivat ainakin puoli vuotta erittäin pysyviä. 